\title{
NEURO-MUSCULAR DYSFUNCTION OF THE LOWER URINARY TRACT IN MULTIPLE SCLEROSIS*
}

\author{
By H. Van Poppel, M.D., ${ }^{1,2}$ R. L. Vereecken, M.D. ${ }^{2}$ and \\ A. LeRUitTE, M.D. ${ }^{1}$ \\ ${ }^{1}$ Division of Urology, National M.S. Centre Melsbroek, Belgium. ${ }^{2}$ Department of \\ Urology, Katholieke Universiteit Leuven, Belgium.
}

Summary. Urological problems in M.S. patients are very frequent and are usually very disabilitating. Complaints will often be misleading. Urodynamic investigations play a most important part in the diagnosis but are carried out with more difficulty than in other patients. The lower urinary tract dysfunction is classified as advised by the I.C.S. Committee. Detailed figures are given in the text.

Evolution of urological disorders in M.S. is unpredictable. Treatment has to be conservative, flexible and reversible if possible. The goal of the treatment is to get a balanced bladder and complications due to urological manipulations must be avoided.

Key words: Multiple sclerosis; Neuropathic bladder; Vesicourethral dysfunction.

\section{Introduction}

THIS PAPER deals with a systematic analysis of urological problems encountered in 500 patients, treated during the last 3 years in the National Multiple Sclerosis (M.S.) Centre of Melsbroek. Attention to urological complications takes an important place in the total care of M.S. patients as although the neurological disturbances are well tolerated by many of these patients who may be euphoric, urological symptoms are regarded as disabling both from social and actual health aspects.

Urological complaints present as the first symptom in M.S. in about 8 per cent of patients (Leruitte et al., 1976). But 70-90 per cent of the patients will sooner or later develop urinary dysfunction in the course of their disease (Rabey et al., I979; Blaivas et al., I979). Many patients tend to minimise their troubles. Minor complaints, such as urgency or dysuria, can disguise severe disturbance of renal function. In our series about two thirds of the patients had urological complaints but not all presented documented neurogenic disorders (Table I).

\section{Symptoms}

THE UROLOGICAL SYMPTOMS can result either from the disease itself or from the therapy which is being given. Thus cyclophosphamide is known to provoke haemorrhagic cystitis, but we also demonstrated that some patients developed significant residual urine, while others presented with frequency and incontinence (Leruitte, I969). Corticosteroids and ACTH often

$\star$ Presented at the Jubilee Conference on Multiple Sclerosis, Copenhagen, Denmark, 6-9 June I982.

All correspondence should be addressed to: H. Van Poppel, M.D., Department of Urology, Univ. Clinics St.-Pieter, Brussels Street 69, B-3000 Leuven, Belgium. 
TABLE I

Urological status in 500 multiple sclerosis patients

\begin{tabular}{lr}
\hline No urological complaints & 2 IO \\
Urological complaints & 290 \\
- Non-neurogenic disorders & 33 \\
- Benign prostatic hypertrophy & IO \\
- Infection & I 8 \\
- Psychogenic & 2 \\
- Cystocoele & 2 \\
- Stricture & I \\
- Proven neurogenic disturbance & I60 \\
(No urodynamic study & 97 ) \\
\hline
\end{tabular}

encourage infection and in some cases retention, while muscle relaxants may aggravate incontinence by relaxation of the external urethral sphincter. An indwelling urinary catheter, used to assist the treatment of a decubitus ulcer, or after tenotomy operation can induce an overactive low compliance bladder with difficulty in re-education. The severity of bladder symptoms due to multiple sclerosis itself seems to parallel the severity of the other neurological symptoms and, in this way, is often related to the duration of the neurological disease. The symptoms can be classified as irritative bladder symptoms (6o per cent of the patients) with urgency, frequency and urgency-incontinence; as obstructive bladder symptoms (33 per cent) with hesitancy, flow decrease, dribbling and retention; or as both irritative and obstructive lesions (Blaivas et al., I979). Finally, multiple sclerosis patients may have urinary infection, benign prostatic hyperplasia, a urethral stricture, a meatal stenosis or an organic bladder neck obstruction, all of which may simulate a neurogenic disorder (Table II).

TABLE II

Causes of urinary symptoms in multiple sclerosis patients

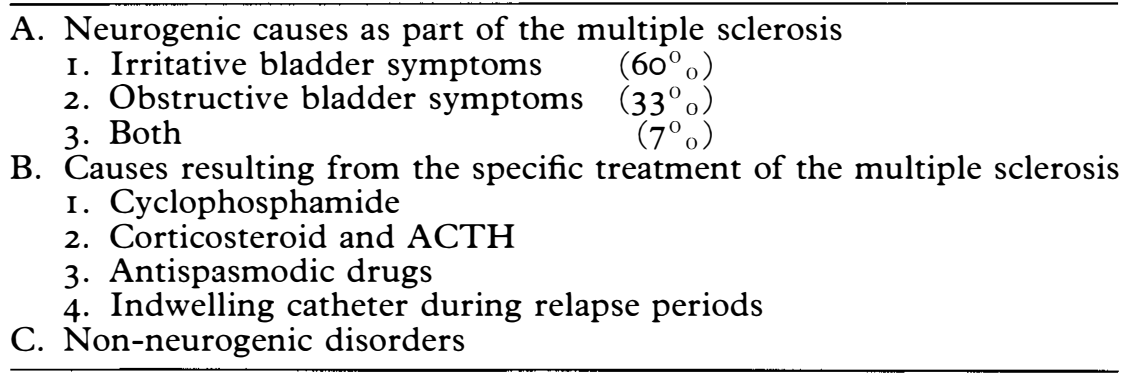

\section{Diagnosis}

These symptoms, even if based on a detailed anamnesis, are often misleading in detecting the underlying urological pathology. Indeed urgency does not necessarily mean an overactive detrusor, and retention does not necessarily mean detrusor areflexia. A routine urological and neuro-urological ex- 
amination is required as soon as symptoms appear. An anorectal examination can reveal a painful anal disease which could induce detrusor-inhibition and urinary retention. Sensation must be recorded.

Each patient is required to complete daily a form in which fluid intake, and voided, or catheterised volumes, incontinence and failed voiding attempts are noted for two or three days.

Intravenous urography provides information about secondary effects on the upper and lower urinary tract. Permicturitional and postmicturitional films may demonstrate residual urine and the site of an organic or functional obstruction. In some patients retrograde procedures will be necessary to reveal urethral pathology.

Urodynamic investigations are essential since anamnesis is not conclusive. However, it should always be borne in mind that they only indirectly measure the effect of a neurological dysfunction. Often the urodynamic findings are affected by an intercurrent infection, during relapse of the multiple sclerosis, by drugs administered for the treatment of the neurological disease, by peripheral spasms, or by bowel or rectal distention by faeces. These are all factors that can interfere with urodynamic patterns (Miller et al., I965).

Uroflowmetry may be impossible because the patient cannot sit upright, or because he leaks urine before sitting on the chair, or simply because he cannot void on command.

Reliable cystometry requires the subtraction of the rectal pressure from the recorded total bladder pressure because of abdominal straining and peripheral spasms. Provocations such as coughing or pelvic floor pinching often cause false findings. Pharmacological studies are valuable (Jensen, I98I). The urethral pressure profile is of limited interest in neurological disorders (Webster et al., 1980).

We have found the needle electrode EMG to be of value, although it is difficult to be certain about the exact location of the needle points (Vereecken and Van Mulders, I982). Evoked anal potentials will demonstrate the integrity of the sacral reflex arc (Vereecken, De Meirsman et al., 1982).

\section{Classification}

Starting from these urodynamic investigations and symptoms we classify our patients, knowing that apparently identical neurologic lesions can give rise to totally different voiding disorders, and that the lesions in multiple sclerosis are only partial and may be mixed in several patients (Jameson, I 982). We use the classification advised by the International Continence Society (I.C.S.): the detrusor muscle may be normal, overactive or underactive; also the urethral closure mechanism can be normal, overactive and underactive. Detruso-urethral dyssynergia is a synchronous contraction of the detrusor with contraction of the bladder neck, the proximal urethra or the striated sphincter. These different functional structures have been exhaustively studied and described (Gosling, 1979). Proprioception and exteroception can also be normal, hypersensitive or hyposensitive (I.C.S. Committee, 1976). In our patients 66 per cent presented with overactive detrusor function, and nearly one out of three patients had a dyssynergia between detrusor and urethra, equally divided for striated and 
TABLE III

Neurological disorders: International Continence Society Classification

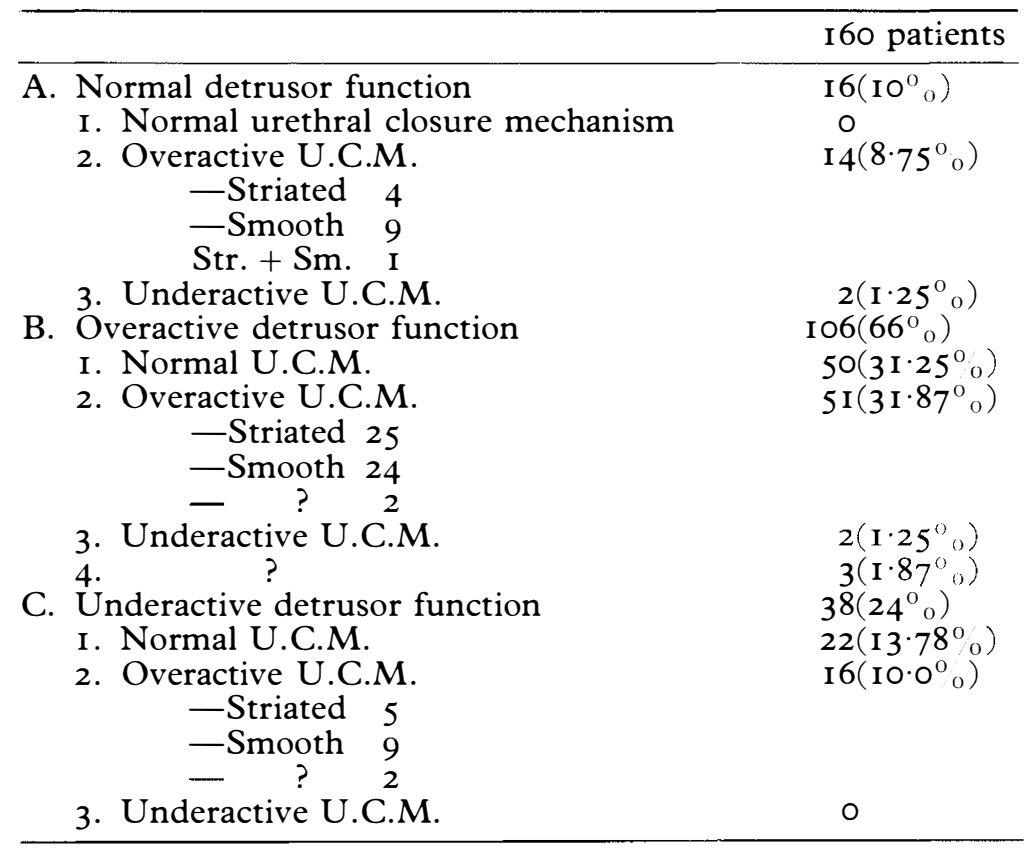

smooth muscle (Table III). Evaluation of sensation was unfortunately unreliable, thus we cannot give figures concerning this parameter.

\section{Evolution}

The evolution of the urological problems in multiple sclerosis patients is unpredictable. Spinal shock rarely occurs at the onset. Most patients have supranuclear partial lesions and overactive detrusor function initially. Progressively, more mixed bladder function is seen. In advanced disease most bladders become underactive, requiring continuous urinary drainage or a diversion procedure (Leruitte et al., I976; Summers, I978). Changes often occur abruptly in multiple sclerosis relapses, and during these episodes patients often have a totally different voiding pattern which quite often necessitates the use of a temporary indwelling urethral catheter.

\section{Treatment}

The treatment of lower urinary tract dysfunction should be conservative, simple and reversible. Bladder pathology can evolve and change continuously so that we must avoid definitive bladder damage if other solutions are available (Piazza et al., 1979). The treatment must be flexible and we know that an effective therapy today may be insufficient tomorrow. Treatment is symptomatic and if cure is obtained it is usually due to a neurological therapeutic success. Treatment is often frustrating and perfect results are rare, but in most patients improvement can be obtained (Schoen- 
TABLE IV

Principle treatment of $\mathrm{I} 60$ multiple sclerosis patients with neuro-urological dysfunction

\begin{tabular}{lr}
\hline I. Medical therapy & I I6 \\
2. Intermittent catheterisation & I 3 \\
$\begin{array}{l}\text { 3 self-catheterisations } \\
\text { 3. Indwelling catheter }\end{array}$ & I 2 \\
$\quad 8$ transurethral & \\
4 suprapubic & 7 \\
4. Bricker derivation & 3 \\
5. Resection of bladder neck \pm prostate & 3 \\
6. Resection of external urethral sphincter & 2 \\
7. Tapotage (Credé) & 2 \\
8. Neuro-surgery & 2 \\
9. Marchall-Marchetti & 2 \\
I0. External prosthesis & I \\
\hline
\end{tabular}

berg et al., I980). Finally, the treatment of lower urinary tract dysfunction must be individualised. The degree of autonomy of the patient, his mental capacity, his social context, his sexual behaviour, and his motivation are important elements in the choice between the various therapeutic modalities (Moriel et al., 1979).

The final goal of treatment is to give the patient a balanced bladder with sufficient capacity and a small residual urine, which he can empty at the time and place he wishes but preserving intact kidney function (Schoenberg et al., I979). Recent statistics (Blaivas et al., I979) mention I.5 per cent deaths from uraemia; close supervision is therefore mandatory so that urosurgical intervention (e.g. Bricker derivations) may be decided upon in good time.

We do not insist on the various medical, urosurgical and neurosurgical procedures set out in Table IV, but would like to draw attention to important complications of seemingly simple urological interventions.

Each urodynamic investigation, and of course each endoscopic manipulation such as lithotripsy, in patients with infected urine, exposes the patient to infectious complications sometimes leading to a fatal outcome from gram-negative septicaemia. I. 5 per cent multiple sclerosis patients die from complicated urinary infections (Blaivas et al., I979), and therefore prophylactive antibiotherapy is imperative for each urological manipulation.

Use of an indwelling urethral catheter as the treatment of the neuropathic bladder is not easily accepted by most urologists. Although urethritis, prostatitis and epididymo-orchitis were not frequently seen, bacteriuria was found in all cases after 4 days of drainage; bladder stones also developed rapidly (Leruitte, I963). Moreover, some patients may present with pseudopapillomatosis which is difficult to distinguish from squamous carcinoma provoked by chronic inflammation (Warren, I98I). The catheter itself can cause intense irritation and provoke detrusor-spasm causing by-pass of urine alongside the catheter; this may result in an irreversible high-compliance spastic bladder. Therefore intermittent catheterisation, the Credé manoeuvre, endoscopic resection or incisions should be tried before making a decision to leave the patient with an indwelling urethral catheter. 


\section{RÉSUMÉ}

Les problèmes urologiques des patients atteints de sclérose en plaques sont très fréquents et sont le plupart du temps mal tolérés. Les plaintes seront souvent minimalisées ou trompeuses. Les investigations urodynamiques prennent une place importante dans le diagnostic mais sont effectuées avec plus de difficultés que dans les patients normaux. Les dysfonctions neurogènes seront facilement classifiées selon la classification qui a été élaborée par le 'International Continence Society Committee'.

L'évolution des troubles urologiques dans la sclérose en plaques est imprévisible. Le traitement devra être conservateur et réversible si possible. On essaiera donc d'obtenir une 'vessie balancée'. Les complications de manipulations urologiques devront être évitées.

\section{ZUSAMMENFASSUNG}

Sehr viele M.S. Patienten haben Urologische Problemen, die sehr frustrierend erfahren werden.

Die Klagen sind oftmals verkleinert und betrügend. Urodynamische Untersuchungen haben eine wichtige Rolle in der Diagnostik, aber sind schwer ausführbar oder interpretierbar.

Die vesiko-urethralen Dysfunktionen werden eingeordnet zufolge der Klassifikation der 'International Continence Society Committee'.

Die Evolution urologischer Affektionen ist sehr unbeständig; also soll die Behandlung konservativ und umkehrbar sein. Komplikationen von urologischen Manipulationen sollen vermeiden werden.

\section{REFERENCES}

Blaivas, J. G., Bhimani, G. \& Labib, K. B. (1979). Vesico-urethral dysfunction in Multiple Sclerosis. F. Urol., I22, I $96-198$.

GosLing, J. (1979). The structure of the bladder and urethra in relation to function. Urol. Clin. N. Am., 6, 3 I-38.

International Continence Society Committee on Standardization (i976). $\mathrm{Br} . \mathcal{f}$. Urol., 48, 32-42.

JAMESON, R. M. (I982). The bladder in multiple sclerosis. F. Roy. Soc. Med., 75, 75-76.

JeNSEN, D. (I98I). Pharmacological studies of the uninhibited neurogenic bladder. F. Oslo City Hospital, 31, 97-I I 4.

LeruitTe, A. (1963). Les méfaits de la sonde à ballonnet dans le traitement des vessies neurogènes de la sclérose en plaques. Acta Urol. Belg., 31, 434-469.

Leruitte, A. (1969). Effets secondaires de l'endoxan sur le fonctionnement vésical. Acta Urol. Belg., 37, 290-297.

Leruitte, A., Ketelaer, P. \& Vereecken, R. (1976). Les troubles mictionnels de la sclérose en plaques. Urol. Int., 31, 230-238.

Miller, H. \& Gates, K. (I965). Bladder dysfunction and multiple sclerosis. Brit. Med. F., I, I $265-1269$.

Moriel, E. Z., Rabey, J. M., Farkas, A., Streifler, M. \& Firstater, M. (i979). Problèmes urologiques chez les malades atteints de sclérose en plaques. Ann. Urol., I3, I I I-I I 5 .

Piazza, D. H. \& Diokno, A. C. (1979). Review of neurogenic bladder in M.S. Urology, 4, 33-35.

Rabey, J. M. Moriel, E. Z., Farkas, A., Firstater, M., Vardi, I. \& Streifler, M. (1979). Detrusor hyperrflexia in M.S. Eur. Neurol., 18, 33-37.

SchoenberG, H. W., Gutrich, J. M. \& BANNo, J. (I979). Urodynamic patterns in M.S. F. Urol., $122,648-650$.

SCHOENBERG, H. W. \& Gutrich, J. M. (1980). Management of vesical dysfunction in M.S. Urology, 16, 444-447.

Summers, J. L. (1978). Neurogenic bladder in the female with M.S. F. Urol., 120, 555-556.

Vereecken, R. L., De Meirsman, J., Puers, B. \& Van Mulders, J. (I982). Electrophysiological exploration of the sacral conus. F. neurol., 227, I35-144.

VereECKen, R. L. \& VAN Mulders, J. (I982). Techniques and value of sphincter EMG in urological problems. Urol. Int., 37, I 52-1 59.

Warren, J. W., Muncie, H. L., Bergquist, E. J. \& Hoopes, J. M. (i98I). Sequelae and management of the urinary infection in patients requiring chronic catheterization. 7. Urol., I25, I-8.

Webster, G. D., Luckhart, J. L. \& Older, R. A. (I980). The evaluation of bladder neck dysfunction. F. Urol., 123, 196-198. 